\title{
Pelatihan Pembuatan Virgin Coconut Oil (VCO) dan Pemanfaatan Sisa Olahannya sebagai Tepung Pembuat Kue
}

\author{
Rosalina Y. Kurang \\ Program Studi Kimia, Fakultas Matematika dan Ilmu Pengetahuan Alam, \\ Universitas Tribuana Kalabahi \\ e-mail Korespondensi: rosalinayuliana89@gmail.com
}

Diterima: Februari 2021; Revisi: Februari 2021; Diterbitkan: Februari 2021

\begin{abstract}
This service aims to increase the knowledge and skills of the community in processing coconut fruit into VCO and the use of coconut dregs to make cake flour. This activity is in partnership with the people of Maukuru Village. The method used in this service is counseling and practice. The results obtained from this dedication were the participants' response was quite high. This can be seen from their presence and enthusiasm in attending counseling and training. Through this activity, it is hoped that the community can continue up to the marketing process so that it can improve the community's standard of living from an economic side and increase the usability of coconut plants.
\end{abstract}

Keywords: Coconut; Virgin Covonut Oil; Flour; Cake

\begin{abstract}
Abstrak
Pengabdian ini bertujuan untuk peningkatan pengetahuan dan keterampilan masyarakat dalam mengolah buah kelapa menjadi VCO dan pemanfaatan ampas kelapa menjadi tepung pembuatan kue. Kegitaan ini bermitra dengan masyaraat Desa Maukuru. Metode yang digunakan dalam pengabdian ini yaitu penyuluhan dan praktek. Hasil yang diperoleh dari pengabdian ini yaitu respon peserta cukup tinggi. Hal ini dapat dilihat dari kehadiran dan antusias mereka dalam mengikuti penyuluhan maupun pelatihan. Melalui kegiatan ini diharapkan masyarakat dapat melanjutkannya sampai pada proses pemasaran sehingga dapat meningkatkan taraf hidup masyarakat dari sisi ekonomi dan peningkatan daya guna tanaman kelapa.
\end{abstract}

Kata Kunci : Kelapa; Virgin Covonut Oil; Tepung; Kue

How to Cite: Kurang Y., R (2021) Pelatihan Pembuatan Virgin Coconut Oil (VCO) dan Pemanfaatan Sisa Olahannya sebagai Tepung Pembuat Kue. Sasambo: Jurnal Abdimas (Journal of Community Service). 3(1), 10-16 DOI: 10.36312/sasambo.v3i1.360

\section{LATAR BELAKANG}

Kelapa merupakan tanaman serbaguna atau tanaman yang mempunyai nilai ekonomi tinggi. Seluruh bagian pohon kelapa dapat dimanfaatkan untuk kepentingan manusia, sehingga pohon ini sering disebut pohon kehidupan (tree of life) (Yulvianti, dkk. 2015). Pengolahan buah kelapa menjadi minyak kelapa murni atau dikenal dengan virgin coconut oil (VCO) merupakan salah satu proses diversifikasi olahan produk dalam rangka meningkatkan nilai guna dari produk. Proses pengolahan 
buah kelapa menjadi minyak kelapa murni dikenal dengan proses basah (wet process) dan proses kering (dry process). Proses basah menggunakan daging buah kelapa segar karena pada proses ini ditambahkan air untuk mengekstraksi minyak, sedangkan proses kering dengan bahan baku kopra (Susanto, 2013). VCO banyak digunakan dalam industri farmasi, kosmetika, susu formula, maupun sebagai minyak goreng mutu tinggi. VCO mempunyai banyak manfaat terutama dalam bidang kesehatan diantaranya merupakan anti bakteri, menjaga kesehatan jantung, membantu mencegah penyakit osteoporosis, diabetes, lever, serta dapat menurunkan berat badan, dan memelihara kesehatan kulit (Marlina, dkk 2017).

Desa Maukuru merupakan salah satu Desa di Kabupaten Alor, Nusa Tenggara Timur yang memiliki tanaman kelapa terbanyak, namun belum dimanfaatkan dengan baik. Pengelolaan tanaman kelapa masih digunakan untuk keperluan sehari-hari. Masyarakat memanfaatkan bagian batang tanaman kelapa sebagai bahan bangunan, lidi daunnya untuk pembuatan sapu dan buahnya untuk pembuatan minyak kelapa. Hasil olahan tersebut belum mengalami peningkatan produk. Agar produk yang dihasilkan memiliki nilai guna yang lebih baik, maka buah kelapa dapat dibuat menjadi VCO. Pembuatan VCO dapat dilakukan melalui beberapa metode yaitu pemanasan, fermentasi, pemancingan (Zulfadli, 2018) dan juga tanpa pemanasan (Sutanto, Agus \& Ratnawati 2017). Pembuatan minyak kelapa oleh masyarakat setempat masih menggunakan metode/cara yang menjadi kebiasaan yaitu dengan proses pemanasan. Minyak kelapa yang dihasilkan selain untuk dijadikan bahan pangan, sebagian dijual untuk kebutuhan ekonomi. VCO saat ini belum banyak dikenal luas sehingga belum banyak masyarakat yang mengolah ataupun mengkonsumsinya. Beda halnya bagi masyarakat yang tinggal di perkotaan, sebagian masyarakat menjadikan VCO sebagai salah satu kebutuhan pangan fungsional untuk kesehatan. Hal inilah yang membuka peluang bagi masyarakat pedesaan untuk mengolah kelapa menjadi VCO sehingga dapat meningkatkan perekonomian masyarakat.

Hasil olahan dari pembuatan VCO menghasilkan residu, yaitu ampas kelapa. Selama ini, masyarakat setempat memanfaatkan ampas kelapa sebagai bahan baku pakan ternak dan masih dianggap sebagai produk samping yang tidak bernilai. Pemanfaatan kelapa masih pada produk primernya saja yaitu dalam bentuk kelapa segar maupun kopra untuk bahan baku minyak goreng sedangkan produk hilir kelapa dan limbah kelapa belum banyak dimanfaatkan dan dikembangkan (Direktorat Jenderal Perkebunan Kementeraian Pertanian, 2013). Pengembangan produk dan pemanfaatan hasil samping dan limbah kelapa akan meningkatkan nilai tambah produk kelapa, sehingga dapat meningkatkan pendapatan petani kelapa (Saepulah, dkk. 2017).

Ampas kelapa dapat dimanfaatkan sebagai bahan pangan dan juga sebagai bahan bakar yang ramah lingkungan. Walaupun ampas kelapa merupakan hasil samping dalam pembuatan santan, tetapi memiliki kandungan serat kasar cukup tinggi. Ampas kelapa mengandung protein, karbohidrat, rendah lemak dan kaya akan serat. Kandungan ini merupakan salah satu kandungan yang sangat dibutuhkan untuk proses fisiologis dalam tubuh manusia (Yulvianti, dkk. M., 2015). Beberapa penelitian telah dilakukan dalam pemanfaatan ampas kelapa sebagai produk olahan pangan, diantaranya biskuit ampas kelapa (BIKA), kerupuk ampas kelapa 
(Krupaska) (Saepulah, dkk. 2017), mie basah (Pratiwi, Hendrarini \& Amalia, 2016) dan juga kue (Triana \& Maita, 2019). Pemanfaatan ampas kelapa dapat juga dijadikan sebagai bahan pangan serat tinggi dalam mencegah konstipasi pada Ibu hamil (Triana \& Maita 2019). Ampas kelapa memiliki potensi biomassa sebagai energi alternatif pengganti bahan bakar minyak tanah yang ramah lingkungan karena masih mengandung minyak yang dapat dikonversi menjadi sumber energi (Hasanuddin \& Idham, 2012).

Serat pangan dapat mengontrol pelepasan glukosa, membantu pengontrolan dan pengaturan diabetes melitus dan obesitas. Serat pangan dalam jumlah yang cukup didalam makanan sangat bagus untuk pencernaan yang baik dalam usus. Serat pangan memiliki fungsi yang sangat penting bagi pemeliharaan kesehatan, pencegahan penyakit dan sebagai komponen penting dalam terapi gizi walaupun tidak dapat dicerna dan tidak diserap oleh saluran pencernaan manusia (Trinidad, 2002; Ramulu dan Rao, 2003; Astawan, 2004 dalam Yulvianti, dkk., 2015).

Pengolahan buah kelapa menjadi VCO dengan proses pemanasan, masih menghasilkan bau yang tengik akibat kadar air yang tinggi sehingga perlu dilakukan dengan metode yang lain agar tidak menghasilkan bau yang tengik. Selain menghasilkan VCO, ampas kelapa juga perlu dimanfaatkan dengan baik untuk kebutuhan pangan. Oleh karena itu pada kegiatan pengabdian ini dilakukan pelatihan pembuatan VCO dengan metode tanpa pemanasan dan pengolahan ampas kelapa menjadi tepung dalam pembuatan produk pangan.

Kegiatan ini bertujuan meningkatkan daya guna tanaman kelapa yang berpotensi menghasilkan VCO dan tepung, menambah ketrampilan untuk meningkatkan pendapatan ekonomi masyarakat dengan penjualan minyak VCO dan memperkenalkan kepada masyarakat inovasi baru tentang cara pengolahan VCO dan pemanfaatan ampas kelapa.

\section{METODE PELAKSANAAN}

Kegiatan pengabdian kepada masyarakat berlangsung selama 3 hari. di Aula Kantor Desa Maukuru, Kec. Alor Timur, Kab. Alor-NTT. Metode yang digunakan dalam kegiatan ini adalah penyuluhan dan praktek. Adapaun tahapan kegiatan adalah sebagai berikut :

a. Pertemuan awal dengan Kepala Desa

Pelaksanaan kegiatan ini diawali dengan pertemuan dengan Kepala Desa untuk membahas rencana kegiatan pengabdian. Dalam pembahasan rencana kegiatan disepakati untuk melakukan penyuluhan/presentasi materi dan pelatihan pembuatan VCO dan pemanfaatan ampas kelapa sebagai tepung. Peserta yang terlibat dalam kegiatan ini tidak hanya ibu-ibu PKK, tetapi juga diikuti oleh tokoh masyarakat, pemuda dan pemudi setempat.

b. Tahap penyuluhan

Pemberian penyuluhan atau penjelasan kepada peserta pelatihan tentang pembuatan VCO dan pemanfaatan ampas kelapa sebagai tepung serta manfaatnya bagi kesehatan. Melalui kegiatan ini diharapkan produk yang dibuat dapat dijual sehingga dapat menambah pendapatan masyarakat di Desa Maukuru.

c. Pembuatan VCO dan tepung ampas kelapa 
Pada tahap ini, peserta di bagi dalam 5 kelompok dan diberikan praktek/pelatihan tentang cara pembuatan VCO dan pemanfaatan ampas kelapa sebagai tepung.

1. Menyiapkan bahan dan alat yang dibutuhkan

Bahan-bahan yang digunakan yaitu kelapa dan air. Alat -alat yang digunakan yaitu toples/plastik ice, baskom dan saringan

2. Proses pembuatan VCO

Kelapa dikupas dari kulitnya kemudian diambil isi kelapa. Selanjutnya diparut sehingga didapatkan parutan kelapa. 1 (satu) buah parutan kelapa di tambakan $500 \mathrm{~mL}$ air dan dicampur kemudian disaring sehingga diperoleh santan kelapa, ampasnya disisikan untuk pembuatan tepung. Santan yang diperoleh selanjutnya dimasukan ke dalam toples bening/plastik ice lalu dibiarkan selama 3 jam hingga diperoleh 2 lapisan. Lapisan bawah yang merupakan air dipisakan dari santan kental. Santan tersebut dibiarkan lagi, jika masih terbentuk lapisan air maka dipisahkan lagi hingga tersisa santan kental. Dibiarkan selama 1x24 jam maka terbentuk 3 lapisan yaitu minyak, blondo dan air. Selanjutnya minyak dipisahkan dari blondo dan air.

3. Proses pembuatan tepung ampas kelapa

Ampas kelapa yang merupakan sisa pembuatan VCO, selanjutnya dicuci sebanyak 2 kali pengulangan. Kemudian dijemur dibawah sinar matahari sampai benar-benar kering. Setelah kering, ampas kelapa ditumbuk/digiling hingga halus dan kemudian diayak untuk memperoleh tepung kelapa. Tepung kelapa siap digunakan untuk pembuatan kue

\section{HASIL DAN PEMBAHASAN}

Pelaksanaan kegiatan ini diawali dengan pertemuan dengan Kepala Desa untuk membahas rencana kegiatan pengabdian. Dalam pembahasan rencana kegiatan disepakati untuk melakukan penyuluhan dan pelatihan pembuatan minyak kelapa murni (VCO) dan pemanfaatan ampas kelapa sebagai tepung. Kegiatan ini tidak hanya diikuti oleh ibu-ibu PKK, tetapi juga diikuti oleh tokoh masyarakat, pemuda dan pemudi setempat. Selain pembuatan minyak kelapa murni (VCO) dan pemanfaatan ampas kelapa sebagai tepung, juga disampaikan cara pengemasan produk untuk promosi dan pemasaran produk serta penggunaan tepung untuk pembuatan kue. Pertemuan dengan Kepala Desa dapat dilihat pada Gambar 1.

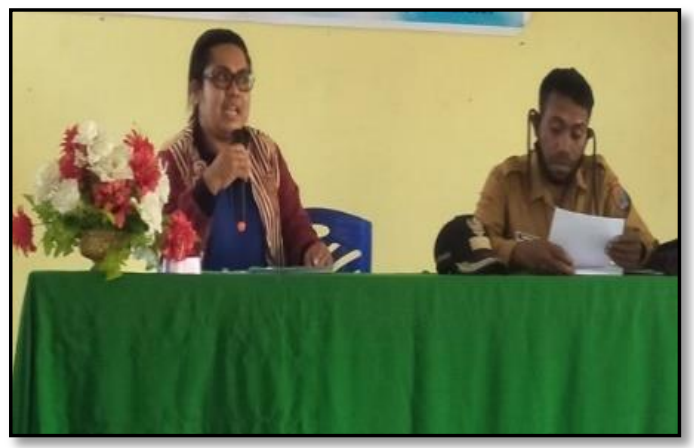

Gambar 1. Pertemuan dengan Kepala Desa

Dalam kegiatan ini, sebelum dilakukan praktek/pelatihan maka diawali dengan pemberian penyuluhan atau penjelasan kepada peserta 
tentang pembuatan VCO dan pemanfaatan ampas kelapa sebagai tepung, serta manfaatnya. Kegiatan penyuluhan dapat dilihat pada Gambar 2.

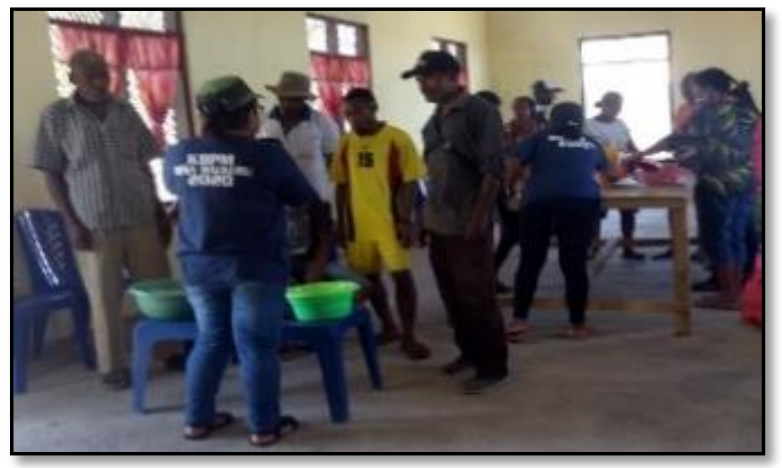

Gambar 2. Penyuluhan kepada peserta

Masyarakat sangat aktif dalam mengikuti penjelasan yang diberikan. $\mathrm{Hal}$ ini dapat dilihat dari rasa antusias mereka dalam memberikan pertanyaan terkait dengan proses pembuatan dan manfaat yang diperoleh dari minyak VCO dan tepung ampas kelapa. Masyarakat mendapatkan tambahan pengetahuan baru yang sangat bermanfaat dan langsung bisa diparaktekkan. Apalagi mereka memiliki tanaman kelapa yang sangat banyak. Selain itu mereka juga mendapatkan pengetahuan tentang teknologi sederhana pembuatan VCO dengan metode tanpa pemanasan yang berbeda dengan yang sudah dikenal selama ini dan juga pemanfaatan ampas kelapa sebagi tepung. Dengan demikian maka pengetahuan tersebut dapat dijadikan sebagai alternatif teknologi pembuatan minyak kelapa yang sangat baik untuk kesehatan masyarakat. Proses pembuatan VCO dan tepung ampas kelapa dapat dilihat pada Gambar 3.
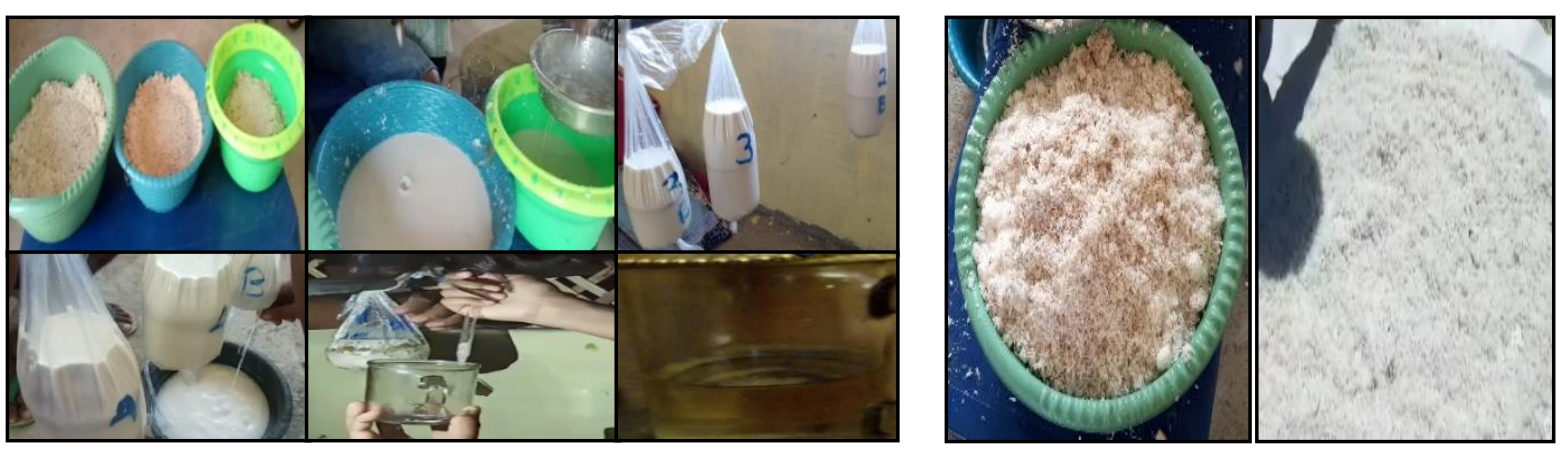

Gambar 3. a. Proses Pembuatan VCO. b. Proses Pembautan tepung Ampas kelapa

VCO yang dihasilkan dari setiap kelompok masing-masing kurang lebih $120 \mathrm{~mL}$ dengan bau khas kelapa segar, tidak tengik, dan tidak berwarna. VCO merupakan merupakan modifikasi proses pembuatan minyak kelapa sehingga dihasilkan produk dengan kadar air dan kadar asam lemak bebas yang rendah, berwarna bening, berbau harum, serta mempunyai daya simpan yang cukup lama. Pembuatan VCO ini memiliki banyak keunggulan yaitu tidak membutuhkan biaya yang mahal karena bahan baku mudah didapat, pengolahan yang sederhana serta tidak menggunakan bahan bakar sehingga kandungan kimia dan nutrisinya tetap terjaga terutama asam lemak dalam minyak. VCO mengandung $92 \%$ asam lemak jenuh, diantaranya asam laurat (48,74\%), asam miristat (16,31\%), 
asam kaprilat (10,91\%), asam kaprat(8,10\%) dan asam kaproat $(1,25 \%)$. VCO mempunyai banyak manfaat terutama dalam bidang kesehatan diantaranya merupakan anti bakteri, menjaga kesehatan jantung, membantu mencegah penyakit osteoporosis, diabetes, lever, serta dapat menurunkan berat badan, dan memelihara kesehatan kulit (Marlina, dkk. 2017). Dari segi ekonomi, VCO mempunyai harga jual yang lebih tinggi dibanding minyak kelapa biasa, sehingga studi pembuatan VCO perlu dikembangkan.

Tepung ampas kelapa adalah tepung yang diperoleh dengan cara menghaluskan ampas kelapa yang telah dikeringkan. Tepung yang dihasilkan masih sedikit berminyak. Tepung ampas kelapa dapat digunakan sebagai bahan baku pembuatan kue. Pengeringan dilakukan untuk mengurangi kadar air yang ada. Proses pengeringan dilakukan dengan dijemur dibawah sinar matahari hingga kering. Penumbukan ampas kelapa kering hingga halus dengan menggunan alu dan lumpang dan diayak/disaring dengan menggunakan tapisan tepung. Kandungan gizi hasil samping ampas kelapa masih bernilai tinggi bila dimanfaatkan sebagai makanan berkadar lemak rendah yang cocok dikonsumsi oleh golongan konsumen yang kegemukan (obesitas) beresiko tinggi terhadap kolesterol dan jantung koroner. Hasil samping ampas kelapa mengandung selulosa cukup tinggi dapat berperan dalam proses fisiologi tubuh (Putri, 2014).

Melalui pelatihan ini maka masyarakat memperoleh teknologi baru yang sederhana dan mudah dimengerti. Selain itu, diharapkan produk yang dibuat dapat dijual sehingga dapat menambah pendapatan masyarakat di Desa Maukuru. Mereka berharap adanya program berkesinambungan untuk memberikan penyuluhan mengenai hal-hal yang berkaitan dengan pengolahan produk-produk lokal yang dapat meningkatkan pendapatan. Pemerintah setempatpun menghimbau kepada peserta agar dengan pengetahuan yang diperoleh maka bisa melanjutkannya dirumah agar dapat meningkatkan daya guna tanaman kelapa dan peningkatan pendapatan ekonomi.

Pelaksanaan kegiatan pengabdian pelatihan pembuatan virgin coconut oil (VCO) dan pemanfaatan sisa olahannya sebagai tepung pembuat kue di Desa Maukuru dapat berjalan sesuai dengan yang diharapkan. Hal ini ditunjukkan dari antusiasnya peserta dengan menyampaikan pertanyaanpertanyaan seputar pembuatan minyak kelapa murni (VCO) dan tepung ampas kelapa serta respon mereka dalam pelathan.

\section{KESIMPULAN}

Dari kegiatan ini dapat disimpulkan bahwa respon peserta cukup tinggi. Hal ini dapat dilihat dari kehadiran mereka dan antusias mereka dalam mengikuti penyuluhan maupun pelatihan.

\section{REKOMENDASI}

Kegiatan pengabdian ini merupakan kegiatan awal untuk peningkatan pengetahuan masyarakat mengenai pembuatan minyak kelapa murni (VCO) dan pemanfaatan ampas kelapa sebagai tepung. Melalui kegiatan ini diharapkan masyarakat dapat melanjutkannya sampai pada proses pemasaran sehingga dapat meningkatkan taraf hidup masyarakat dari sisi ekonomi dan peningkatan daya guna tanaman kelapa. 


\section{UCAPAN TERIMAKASIH}

Ucapan terima kasih kami sampaikan kepada Universitas Tribuana Kalabahi yang telah memberikan dana pengabdian, dan kepada semua pihak yang telah mendukung kegiatan pengabdian ini.

\section{DAFTAR PUSTAKA}

Direktorat Jenderal Perkebunan Kementerian Pertanian. (2013). Peningkatan Produksi, Produktivitas dan Mutu Tanaman Tahunan : Pedoman Teknis Pengembangan Tanaman Kelapa Tahun 2014. Jakarta.

Hasanuddin dan Idham, H. L. (2012). Pembuatan Biopelet Ampas Kelapa Sebagai Energi Bahan Bakar Alternatif Pengganti Minyak Tanah Ramah Lingkungan. Laporan Penelitian Berorientasi Produk Dana PNBT anggaran 2012. Jurusan Teknik Industri Fakultas Teknik Universitas Negeri Gorontalo.

Marlina, Wijayanti, D., Yudiastari, I. P., Safitri, L. (2017). Pembuatan Virgin Coconut Oil dari Kelapa Hibrida menggunakan metode Penggaraman Dengan $\mathrm{NaCl}$ dan Garam Dapur, Jurnal Chemurgy, 1(2), 7-12.

Pratiwi, E. D., Hendrarini, L., Amalia, R. (2016). Pemanfaatan Limbah Ampas Kelapa (Cocos nucifera Lin) Sebagai Tepung Dalam Pembuatan Mi Basah, Jurnal Kesehatan Lingkungan, 8(2), 51 - 56.

Putri, M. F. (2014). Kandungan Gizi dan Sifat Fisik Tepung Ampas Kelapa sebagai Bahan Pangan Sumber Serat, TEKNOBUGA, 1(1), 32-43.

Saepulah, A., Julita,U., Yusuf, T., Cahyanto, T. (2017). Inovasi Produk Olahan Pangan Melalui Pemanfaatan Limbah Organik Ampas Kelapa Untuk Meningkatkan Ekonomi Masyarakat Kabupaten Bandung Jawa Barat, J. ISTEK, X(2), 91-106.

Susanto, T. (2013). Perbandingan Mutu Minyak Kelapa yang di Proses Melalui Pengasaman dan Pemanasan Sesuai SNI 29022011, Jurnal Hasil Penelitian Industri, 26(1), 1-10

Sutanto, T. D., Agus, M.Hp, Ratnawati, D. (2017). Pembuatan Virgin Coconut Oil (VCO) Dengan Metode Tanpa Pemanasan Sebagai Upaya Meningkatkan Kesehatan Masyarakat, Jurnal Dharma Raflesia, XVI(1), 55-59.

Triana, A., Maita, L. (2019). Pemanfaatan Tepung Ampas Kelapa Sebagai Bahan Baku Pembuatan Kue Serat Tinggi Untuk Pencegahan Konstipansi Pada Ibu Hamil, GEMASSIKA, 3(1), 19-26.

Yulvianti, M., Ernayati, W.,Tarsono, M. Alfian, R. (2015). Pemanfaatan Ampas Kelapa Sebagai Bahan Baku Tepung Kelapa Tinggi Seratdengan Metode Freeze Drying, Jurnal Integrasi Proses. 5(2), 101 107.

Zulfadli, T. (2018). Kajian Sistem Pengolahan Minyak Kelapa Murni (Virgin Coconut Oil) Dengan Metode Pemanasan. International Journal of Natural Science and Engineering, 2(1), 34-41. 